\title{
Aplikasi Pupuk Bokashi Padat Berbahan Dasar Berbeda terhadap Pertumbuhan dan Produksi Tanaman Krokot (Portulaca oleracea L.)
}

Maria Irma Naisoko ${ }^{\mathrm{a}}$

${ }^{a}$ Fakultas Pertanian, Universitas Timor, Kefamenanu, TTU - NTT, 85613, Indonesia, email: irmanaisoko43@gmail.com

${ }^{a}$ Faculty of Agriculture, Timor University, Kefamenanu, TTU - NTT, 85613, Indonesia, email: irmanaisoko43@ gmail.com

\section{Article Info}

\section{Article history:}

Received 26 Maret 2021

Received in revised form 03 April 2021

Accepted 10 April 2021

DOI:

https://doi.org/10.32938/ja.v6i2.1351

\section{Keywords:}

\section{Bokashi}

Krokot

Pertumbuhan dan Produksi.

\section{Abstrak}

Tujuan dari penelitian ini untuk mengetahui aplikasi pupuk bokashi padat berbahan dasar berbeda terhadap pertumbuhan dan produksi tanaman krokot (Portulaca oleracea. L.). Penelitian ini dilaksanakan pada tanggal 2 Maret 2020, bertempat di lahan Pertanian Universitas Timor. Metode yang digunakan dalam penelitian ini merupakan percobaan lapangan yang menerapkan Rancangan Acak Lengkap (RAL) yang terdiri dari 4 perlakuan dan 4 ulangan sehingga terdapat 16unit satuan percobaan. Perlakuan yang diuji terdiri dari $\mathrm{R}_{0}$ : Tanpa pupuk Bokashi (kontrol), $\mathrm{R}_{1}$ : Pupuk Bokashi Berbahan dasar Ekskreta Ayam, $\mathrm{R}_{2}$ : Pupuk Bokashi Berbahan dasar Feses Sapi dan $\mathrm{R}_{3}$ : Pupuk Bokashi Berbahan dasar Feses Kambing. Adapun variabel yang diamati dalam penelitian ini adalah panjang penyebaran $(\mathrm{cm})$, diameter batang $(\mathrm{mm})$, jumlah anakan, berat segar tanaman (gram) dan berat kering tanaman (gram). Hasil penelitian menunjukkan bahwa pemberian bokashi padat berbahan dasar ekskreta ayam menghasilkan panjang penyebaran tanaman terbaik yakni $8.53 \mathrm{~cm}$ sedangkan bokashi padat berbahan dasar feses sapi yang terbaik dalam meningkatkan diameter batang $(0,39 \mathrm{~mm})$; jumlah anakan $(2,11)$ berat segar tanaman (3.17 gram) dan berat kering tanaman (0,44 gram). Dapat disimpulkan bahwa pemberian bokashi berbahan dasar ekskreta ayam dan feses sapi sangat aktif dalam meningkatkan nilai pertumbuhan dan produksi tanaman krokot karena mengandung unsur hara yang dibutuhkan untuk pertumbuhan tanaman.

\section{Pendahuluan}

Salah satu pakan lokal yang banyak digunakan sebagai pakan ternak babi adalah krokot. Krokot merupakan tanaman lokal yang tumbuh dan mampu beradaptasi dengan baik dilingkungan lahan kering seperti diwilayah Nusa Tenggara Timur. Oleh masyarakat di pedesaan, biasanya krokot bermanfaat multifungsi yaitu selain pakan ternak babi juga sebagai tanaman obat-obatan. Tanaman ini dalam bidang peternakan masih diangap sebagai tanaman gulma.

Krokot (Portulaca oleracea L.) memiliki ciri batang yang berbentuk bulat tumbuh tegak sebagian atau seluruhnya terletak di atas tanah tanpa mengeluarkan akar. Daun krokot memiliki warna hijau dengan batang kemerahan dan berdaun tunggal yang tebal (Dalimartha, 2009). Di daerah Sunda, tumbuhan krokot disebut gelang, masyarakat Jawa menyebutnya tumbuhan krokot, di Madura disebut resereyan dan di Maluku disebut jalu-jalu kiki sedangkan di Wilayah Timor Tengah Utara disebut Kleob. Di antara jenis gulma, krokot (Portulaca oleracea L.) mempunyai konsentrasi asam lemak omega-3 tertinggi. Tumbuhan krokot dapat dibudidayakan dengan mudah, yaitu melalui biji krokot yang mengering dan jatuh ke permukaan tanah maka akan tumbuh dengan sendirinya. Untuk memperbaiki pertumbuhan tanaman maka perlu dilakukan penambahan unsur hara berupa penggunaan pupuk organik.

Pupuk organik umumnya merupakan pupuk lengkap artinya mengandung beberapa unsur hara makro dan mikro dengan jumlah yang tertentu (Lingga dan Marsono, 2003). Menurut Sutanto (2002), pupuk organik merupakan bahan pembenah tanah yang lebih baik daripada bahan pembenah buatan, walaupun pada umumnya pupuk organik mempunyai kandunga hara makro N, P, K yang rendah tetapi mengandung hara mikro dalam jumlah yang cukup yang sangat diperlukan dalam pertumbuhan tanaman. Ditambahkan oleh Indriani (2001), penggunaan pupuk organik lebih menguntungkan dibandingkan dengan pupuk anorganik karena tidak menimbulkan sisa asam organik di dalam tanah dan tidak merusak tanah jika pemberiannya berlebihan. Salah satu jenis pupuk organik diantaranya adalah bokashi.

Bokashi adalah kompos yang dihasilkan melalui fermentasi dengan pemberian Effective microorganism-4 (EM-4) yang merupakan salah satu aktivator untuk mempercepat proses pengomposan (Indriani, 2001). EM-4 mengandung $90 \%$ bakteri Lactobacillus sp (Bakteri penghasil asam laktat) pelarut fosfat, bakteri fotosintetik, Steptomyces sp, jamur pengurai selulosa dan ragi. Pemberian bokashi yang difermentasikan dengan EM-4 merupakan salah satu cara untuk memperbaiki sifat fisik, kimia dan biologi tanah serta dapat menekan hama dan penyakit serta meningkatkan mutu dan jumlah produksi tanaman (Nasir, 2008). Bahan-bahan pembuatan bokashi biasanya adalah bahan-bahan organik seperti kotoran ternak, dedaunan dan bahan tambahan lain seperti dedak padi. Untuk mempercepat proses fermentasi maka perlu ditambahkan akselerator seperti EM-4. Dalam proses pembuatan bokash terjadi peristiwa pengomposan yang merupakan proses perombakan bahan organik yang melibatkan mikroorganisme dalam keadaan terkontrol (Lingga dan Marsono, 2003). Proses perombakan atau dekomposisi bahan organik tersebut menjadi zat organik berbentuk ion tersedia bagi tanaman mendukung ketersediaan unsur hara, baik yang makro ataupun yang mikro. Upaya pemupukan sudah jelas mampu membantu penyediaan unsur hara serta akan menjadi lebih efektif apabila dilaksanakan dengan pemilihan cara, dosis, dan jenis pupuk yang tepat dan sesuai dengan kondisi tanaman.

Pertumbuhan adalah proses dalam kehidupan tanaman yang mengakibatkan perubahan ukuran tanaman semakin besar dan juga yang menentukan hasil tanaman (Sitompul dan Guritno, 1995). Pertambahan ukuran tubuh tanaman secara keseluruhan merupakan hasil dari pertambahan ukuran bagian-bagian tanaman akibat dari pertambahan jaringan sel yang dihasilkan oleh pertambahan ukuran sel. Salisbury dan Ross (1995) menjelaskan bahwa terdapat dua macam pengukuran pertumbuhan yang lazim digunakan untuk mengukur pertambahan volume atau ukuran, yang sering ditentukan dengan cara mengukur perbesaran ke satu arah atau dua arah, seperti tinggi, diameter dan luas.

Walaupun krokot masuk kategori tanaman liar, krokot dapat ditanam dan dibudidayakan untuk kebutuhan pakan ternak. Dalam proses budidaya krokot, tentu ada perlakuan khusus agar tanaman krokot dapat tumbuh subur. Salah satu bentuk perlakuan terhadap tanaman krokot ialah penggunaan pupuk bokashi padat

\section{Metode}

\subsection{Waktu dan Tempat}

Penelitian dilaksanakan di lahan percobaan Fakultas Pertanian Universitas Timor, Kelurahan Sasi, Kecamatan Kota Kefamenanu, Kabupaten Timor Tengah Utara, penelitian berlangsung selama 45 hari atau selama 1 masa produksi.

\subsection{Materi Peneltian}

\subsubsection{Alat dan bahan}

Alat yang digunakan meliputi: cangkul/skop, mistar, linggis, kalkulator, alat tulis menulis, kamera. Sedangkan bahan yang digunakan yaitu: tanaman krokot, Bokashi yang terbuat dari beberapa bahan antara lain: kotoran sapi, kotoran kambing, ekskreta ayam, dedak padi, EM4, dan gula pasir.

\subsubsection{Rancangan Penelitian}

Penelitian ini merupakan percobaan lapangan yang menerapkan Rancangan Acak Lengkap (RAL) yang terdiri dari 4 perlakuan dan 4 ulangan sehingga terdapat 16 unit satuan percobaan. Perlakuan yang diuji terdiri dari: $\mathrm{R}_{0}$ : Tanpa pupuk Bokashi (kontrol)

$\mathrm{R}_{1}$ : Pupuk Bokashi Berbahan Dasar Ekskreta Ayam

$\mathrm{R}_{2}$ : Pupuk Bokashi Berbahan Dasar Feses Sapi

$\mathrm{R}_{3}$ : Pupuk Bokashi Berbahan Dasar Feses Kambing

\subsection{Prosedur Penelitian}

\subsubsection{Pembuatan Bokashi Padat}

Pembuatan pupuk bokashi sebaiknya dilakukan sebelum persiapan lahan sehingga disamping menunggu proses fermentasinya dapat melakukan persiapan lahan. Kebutuhan dari setiap jenis pupuk bokashi terlihat pada Tabel 1

Tabel 1. Konsentrasi Campuran Pupuk Yang Difermentasi

\begin{tabular}{llll}
\hline Jenis Pupuk & Bahan & Jumlah & Satuan \\
\hline \multirow{5}{*}{ Ekskreta Ayam } & Ekskreta ayam & 50 & $\mathrm{Kg}$ \\
& Daun gamal & 20 & $\mathrm{~kg}$ \\
& Dedak padi & 4 & $\mathrm{~kg}$ \\
& EM4 & 250 & $\mathrm{ml}$ \\
& Gula & 1 & $\mathrm{~kg}$ \\
& Air & 10 & liter \\
\hline \multirow{5}{*}{ Feses Sapi } & Feses sapi & 50 & $\mathrm{Kg}$ \\
& Daun gamal & 20 & $\mathrm{~kg}$ \\
& Dedak padi & 4 & $\mathrm{~kg}$ \\
& EM4 & 250 & $\mathrm{ml}$ \\
& Gula & 1 & $\mathrm{~kg}$ \\
& Air & 10 & $\mathrm{liter}$ \\
\hline \multirow{5}{*}{ Feses Kambing } & Feses kambing & 50 & $\mathrm{Kg}$ \\
& Daun gamal & 20 & $\mathrm{~kg}$ \\
& Dedak padi & 4 & $\mathrm{~kg}$ \\
& EM4 & 250 & $\mathrm{ml}$ \\
& Gula & 1 & $\mathrm{~kg}$ \\
& Air & 10 & liter \\
\hline
\end{tabular}


Cara pembuatan bokashi padat

1) Bahan-bahan yang disiapkan adalah: $50 \mathrm{~kg}$ feses sapi, ekskreta ayam dan feses kambing, $20 \mathrm{~kg}$ daun gamal, dedak padi $4 \mathrm{~kg}$, EM4 $250 \mathrm{ml}$, gula 1 $\mathrm{kg}$, Air 10 liter.

2) Disimpan pada tempat yang tidak dikenai air hujan. Buat lubang berbentuk persegi panjang di atas tanah tersebut dengan lebar $1 \mathrm{~m}$, panjang 2 meter dan dalam $40-60 \mathrm{~cm}$, atau sesuaikan ukuran lubang dengan banyak bahan baku.

3) Daun gamal dicacah kecil-kecil (2-3 cm), campuran bahan-bahan organik yang telah disiapkan, aduk hingga merata dengan menggunakan sekop.

4) mengencerkan larutan EM4 ambil $250 \mathrm{ml}$ larutan campurkan dengan 10 liter air bersih dan $1 \mathrm{~kg}$ gula pasir. kemudian siramkan bahan baku diaduk menggunakan sekop.

5) Tutup rapat lubang fermentasi dengan karung, diamkan hingga 7-14 hari.

6) Setelah 14 hari biasanya pupuk bokashi sudah berbentuk dan sudah dapat di aplikasikan langsung ke tanaman.

\subsubsection{Penyiapan Lahan}

Penelitian diawali dengan pembersihan lahan yang dipakai dan dibuat dalam bentuk 16 buah bedeng yang terbagi dengan 4 blok dengan ukuran tiap bedeng 1,5 x 1,5 (P x L) dengan jarak antara bedeng $30 \mathrm{~cm}$ dan jarak antara blok $50 \mathrm{~cm}$ dan luas lahan 10x10 m. Jenis pupuk yang digunakan adalah pupuk bokashi. Kebutuhan pupuk yang akan digunakan sebanyak $36 \mathrm{~kg}$ untuk ke 3 jenis perlakuan pupuk bokashi.

\subsubsection{Pemberian Perlakuan}

Setelah pembuatan bedeng dilanjutkan dengan pembuatan lubang tanam dengan ukuran dalam lubang $10 \mathrm{~cm}$, jarak antar lubang $40 \mathrm{~cm}$, jarak antar baris $60 \mathrm{~cm}$, pemberian pupuk setiap lubang tanam 250 gram. Perlakuan sesuai kebutuhan pupuk yang akan digunakan sebanyak $36 \mathrm{~kg}$ untuk ke 3 jenis perlakuan pupuk bokashi.

\subsubsection{Penanaman}

Pemindahan bibit tanaman krokot ke bedeng dilakukan dengan cara membongkar tanaman dengan menggunakan linggis dan air. Penanaman dalam bedeng dilakukan secara hati-hati untuk menghindari kerusakan akar. Tanaman yang telah ditanam kemudian diberi label sesuai dengan perlakuan dan disiram.

\subsubsection{Pemeliharaan}

Kegiatan pemeliharaan meliputi penyiraman setiap pagi dan penyiangan terhadap gulma.

\subsubsection{Pengambilan Data}

Dalam kegiatan Pengambilan data dilakukan secara langsung di lapangan yaitu dengan mengukur panjang penyebaran, diameter batang, jumlah anakan, berat segar dan berat kering tanaman selama 1 massa produksi. Pengukuran dilakukan sebanyak 6 kali, pada umur 7, 14, 21, 28, 35 dan 42 HST (Hari Setelah Tanam).

\subsection{Variabel Penelitian}

Dalam penelitian ini variabel yang diamati adalah sebagai berikut:

\subsubsection{Panjang Penyebaran (cm)}

Mengukur dari pangkal batang bagian bawah sampai ujung tanaman dan hasilnya dihitung melalui pendekatan rumus: $\mathrm{PB}=\underline{\mathrm{PB} 1+\mathrm{PB} 2+\mathrm{PB} 3+\mathrm{PB} 4+\mathrm{PB} 5+\mathrm{PB} 6}$

\section{Keterangan:}

PB1 = Panjang Penyebaran pengukuran pertama

PB2 = Panjang Penyebaran pengukuran kedua

PB3 = Panjang Penyebaran pengukuran ketiga

PB4 = Panjang Penyebaran pengukuran keempat

PB5 = Panjang penyebaran pengukuran kelima

PB6 = Panjang penyebaran pengukuran keenam

$\mathrm{T}=$ Waktu (Minggu)

\subsubsection{Diameter Batang (mm)}

Pengamatan dilakukan setiap 2 minggu sekali dengan cara mengukur diameter batang sekitar $2 \mathrm{~cm}$ dari pangkal batang dengan cara menggunakan jangka sorong.

$\mathrm{DB}=\underline{\mathrm{DB} 1+\mathrm{DB} 2+\mathrm{DB}+\mathrm{DB} 4+\mathrm{DB} 5+\mathrm{DB} 6}$

\section{Keterangan:}

DB1 =Diameter batang pengukuran pertama

DB2 $=$ Diameter batang pengukuran kedua

DB3 = Diameter batang pengukuran ketiga

DB4 = Diameter batang pengukuran keempat

DB5 = Diameter batang pengukuran kelima

DB6 $=$ Diameter batang pengukuran keenam

$\mathrm{T}=$ Waktu (Minggu)

\subsubsection{Jumlah Anakan}

Dihitung pada jumlah anakan yang telah muncul pada ruas batang tanaman atau cabang utama.

$\mathrm{JA}=\frac{\mathrm{JA} 1+\mathrm{JA} 2+\mathrm{JA} 3+\mathrm{JA} 4+\mathrm{JA} 5+\mathrm{JA} 6}{\mathrm{~T}}$

Keterangan:

JA1 = Jumlah anakan pengukuran pertama

JA2 = Jumlah anakan pengukuran kedua

JA3 = Jumlah anakan pengukuran ketiga

JA4 = Jumlah anakan pengukuran keempat

JA5 = Jumlah anakan pengukuran kelima

JA6 = Jumlah anakan pengukuran keenam

$\mathrm{T}=$ Waktu (Minggu)

\subsubsection{Berat Segar Tanaman (gram)}

Dipanen keseluruhan bagian tanaman (daun, batang dan akar), dibersihkan, dikeringkan, kemudian ditimbang menggunakan timbangan analitik.

\subsubsection{Berat Kering Tanaman (gram)}

Daun, batang, dan akar dimasukkan ke dalam oven pada temperatur $100^{\circ} \mathrm{C}$ sampai beratnya konstan, kemudian ditimbang.

\subsection{Analisis Data}

Data yang diperoleh ditabulasi kemudian dianalisis menggunakan analisis sidik ragam (Anova) sesuai dengan rancangan yang digunakan yaitu rancangan acak lengkap (RAL) dilanjutkan dengan uji Duncan dengan menggunakan program SAS versi 9.0. sesuai petunjuk Steel and Torrie (1995).

\section{Hasil dan Pembahasan}

3.1 Panjang Penyebaran

Panjang penyebaran menggambarkan laju pertumbuhan tanaman yang dapat diukur persatuan waktu. Panjang penyebaran pada tanaman sangat berpengaruh terhadap cover crop area dimana penutupan permukaan tanah akibat penyebaran tanaman akan menghasilkan kondisi ekosistem tanah yang lebih baik. Hasil pengukuran panjang penyebaran tanaman krokot yang mendapat aplikasi pupuk bokashi padat berbahan dasar berbeda dapat dilihat pada Gambar 1.

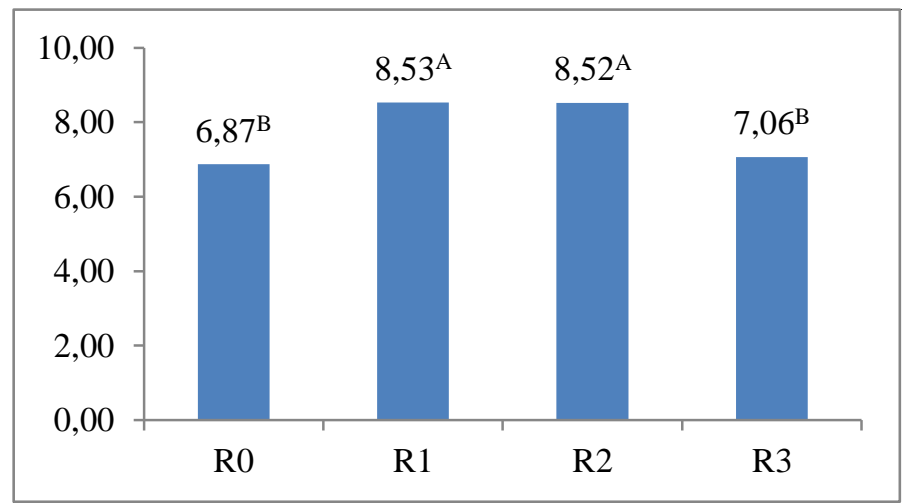

Gambar 1. Panjang Penyebaran (cm). Superskrip yang berbeda pada gambar diatas menunjukkan berbeda nyata $(\mathrm{P}<0,05)$

Pada Gambar 1 menunjukkan bahwa panjang penyebaran tanaman krokot yang diberi perlakuan bokashi padat berbahan dasar berbeda menghasilkan panjang penyebaran yang terpanjang pada perlakuan R1 yaitu $8,53 \mathrm{~cm}$ dan panjang penyebaran terendah pada perlakuan R0 yaitu $6,87 \mathrm{~cm}$. Hasil analisis sidik ragam memperlihatkan bahwa aplikasi pupuk bokashi dari bahan dasar berbeda berpengaruh nyata $(\mathrm{P}<0,05)$ terhadap panjang penyebaran tanaman krokot yang dihasilkan. Hasil uji lanjut dengan uji Duncan menunjukkan bahwa antara perlakuan R1-R2 dan perlakuan R0-R3 berbeda tidak nyata sedangkan pada perlakuan R1-R0; R1-R3; R2-R0; dan R2R3menunjukkan berbeda nyata.Halini diduga karena berkaitan dengan kemampuan dan kelebihan dari tanaman krokot itu sendiri.Salah satu kelebihan tanaman krokot adalah memiliki sifat adaptasi yang baik terhadap lingkungan. Tingginya panjang penyebaran pada perlakuan R1diduga disebabkan karena bokashi berbahan dasar ekskreta ayam yang ditambahkan ke dalam tanah dapat menyumbangkan unsur Nitrogen $(\mathrm{N})$ berfungsi untuk merangsang pertumbuhan tanaman secara keseluruhan, terutama batang, cabang dan daun. Unsur Phosfor (P) berfungsi untuk merangsang pertumbuhan akar, khususnya akar benih dan tanaman mudah. Unsur Kalium (K) berfungsi untuk membantu pembentukan protein dan karbohidrat, memperkuat tanaman sehingga daun, biji, buah tidak mudah gugur. Sehingga meningkatkan ketersediaan unsur-unsur tersebut dalam tanah (Syam, 2003; Nguyen dan Shindo, 2011).

Ekskreta ayam mempunyai kadar unsur hara dan bahan organik yang tinggi serta kadar air yang rendah. Setiap ekor ayam kurang lebih menghasilkan ekskreta per hari sebesar 6,6\% dari bobot hidup (Taiganides, 1977). Ekskreta 
ayam memiliki kandungan unsur hara $\mathrm{N} \mathrm{1 \% ,P} \mathrm{0,80 \% ,} \mathrm{K} \mathrm{0,40 \%} \mathrm{dan} \mathrm{kadar} \mathrm{air}$ $55 \%$ (Lingga, 1996). Secara kimia fungsi bahan organik tanah adalah memberikan sumbangan hara melalui proses dekomposisi. Hal ini tidak jauh berbeda dengan feses sapi yakni mengandung $\mathrm{N} 0,40-2 \%, \mathrm{P} 0,20-0,50 \%, \mathrm{~K}$ $0,10-1,5 \%$. Dengan kandungan unsur hara yang demikian tanaman krokot mampu untuk menghasilkan panjang penyebaran yang cukup tinggi.

Bokashi dapat meningkatkan dan memperbaiki kandungan unsur hara, hal ini disebabkan karena bokashi dari ekskreta ayam mengandung bahan organik yang dapat meningkatkan kesuburan tanah.Selain itu bokashi juga mengandung unsur hara makro (N,P, dan $\mathrm{K}$ ) dan unsur hara mikro seperti $\mathrm{Ca}, \mathrm{Mg}, \mathrm{B}, \mathrm{S}$, dan lain-lain. Pemberian bokashi dengan dosis yang lebih banyak akan semakin memperbaiki kandungan unsur hara tanah. Hal ini sesuai dengan pendapat Kesumaningwati dan Arpendi, (2020), bahwa penambahan bahan organik (bokashi) ke dalam tanah dapat meningkatkan kandungan bahan organik dan unsur hara dalam tanah. Penambahan bahan bokashi kedalam tanah akan mampu menyediakan nutrient bagi tanaman sehingga dapat dimanfaatkan dalam proses pembelahan sel dan perpanjangan ukuran tanaman melalui mekanisme perombakan dan penyerapan unsur hara dengan bantuan mikroorganisme tanah.

\subsection{Diameter Batang}

Pertumbuhan diameter batang dipengaruhi oleh aktivitas fotosistesis, dimana pertumbuhan diameter berlangsung apabila hasil fotosintesis seperti respirasi, penggantian daun, pertumbuhan akar dan tinggi telah terpenuhi (Davis dan Jhonson, 1987). Adapun hasil pengukuran terhadap diameter batang tanaman krokot yang mendapat aplikasi pupuk bokashi padat berbahan dasar berbeda dapat dilihat pada Gambar 2.

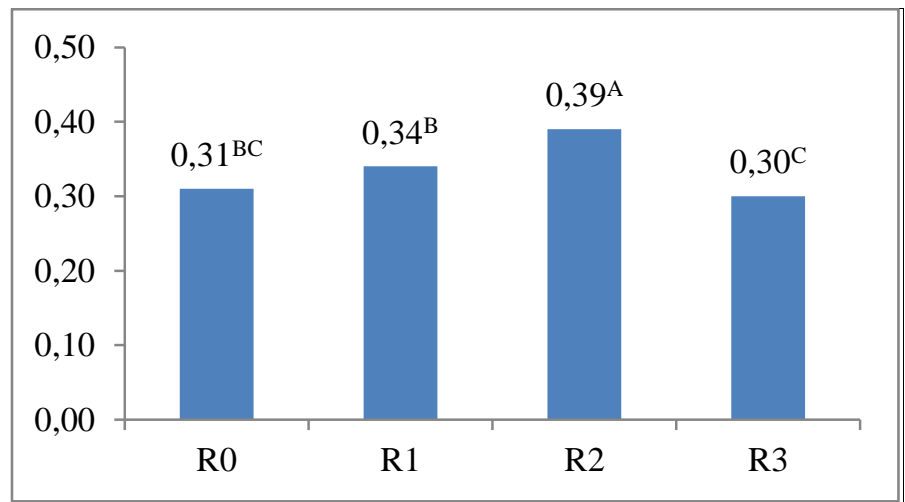

Gambar 2. Diameter Batang (mm). Superskrip yang berbeda pada gambar diatas menunjukkan berbeda nyata $(\mathrm{P}<0,05)$

Pada Gambar 2 memperlihatkan bahwa penggunaan bokashi padat berbahan dasar berbeda pada tanaman krokot menghasilkan perkembangan ukuran diameter batang yang terbaik (besar) pada perlakuan R2 yakni 0,39 mm dan dibawahnya menyusul secara berurutan perlakuan $\mathrm{R} 1(0,34 \mathrm{~mm})$; perlakuan R0 $(0,31 \mathrm{~mm})$ dan terakhir perlakuan $\mathrm{R} 3(0,30 \mathrm{~mm})$. Hasil analisis sidik ragam terhadap diameter batang tanaman krokot menunjukkan adanya pengaruh yangnyata $(\mathrm{P}<0,05)$ terhadap ukuran diameter batang yang dihasilkan. Uji Duncan menunjukkan bahwa semua pasangan perlakuan menunjukan perbedaannyata. Meningkatnya diameter batang pada perlakuan R2 diduga karena pengaruh penggunaan pupuk bokashi kotoran sapi yang merupakan salah satu alternatif dalam penerapan teknologi pertanian organik yang berwawasan lingkungan dan berkelanjutan. Kotoran sapi merupakan bahan organik yang mempunyai prospek yang baik dijadikan pupuk organik (bokashi), karena mempunyai kandungan unsur hara yang cukup tinggi (Tola et al., 2007). Kotoran sapi mengandung unsur hara antara lain nitrogen 0,33\%, fosfor $0,11 \%$, kalium $0,13 \%$, kalsium $0,26 \%$. Pada umumnya pupuk organik mengandung hara makro $\mathrm{N}, \mathrm{P}, \mathrm{K}$ rendah, tetapi mengandung hara mikro dalam jumlah cukup yang sangat diperlukan untuk pertumbuhan tanaman. Unsur Nitrogen $(\mathrm{N})$ berfungsi sebagai penyusun asam amino (protein), asam nukleat, nukleotida serta klorofil. Unsur Phosfor (P) berfungsi sebagai penyimpan dan menyalurkan energi untuk semua aktivitas metabolisme tanaman. Unsur Kalium (K) berfungsi sebagai aktivator enzim yang berpartisipasi dalam proses metabolisme tanaman. Hasil fermentasi bahan organik yang dilakukan oleh EffectiveMikroorganisme-4 (EM4) adalah asam laktat, asam amino, yang dapat diserap langsung oleh tanaman sebagai antibiotik yang mampu menekan pertumbuhan mikroorganisme yang merugikan (Higa and James, 1997). Unsurhara yang dibutuhkan tanaman diperoleh dari tanah hasil dari dekomposisi bahan organik yang akan memperbaiki kesuburan fisik, kimia dan biologi tanah. Ketersediaan unsur hara tanah di daerah tropis tidak dapat mencukupi kebutuhan tanaman untuk pertumbuhan dan produksi, sehingga perlu penambahan pupuk sebagai sumber unsur hara (Winata et al., 2012).

Hal yang sama dijelaskan oleh Davis dan Jhonson (1987), bahwa setidaknya terdapat tiga faktor lingkungan (tempat tumbuh) dan satu faktor genetik (intern) yang sangat nyata berpengaruh terhadap pertumbuhan diameter maupun tinggi, yaitu kandungan nutrien mineral tanah, kelembaban tanah dan cahaya matahari, serta keseimbangan sifat genetik antara pertumbuhan tinggi dan diameter suatu pohontergantung dari seberapa besar tanaman dapat menyerap hara dalam tanah dan faktor eksternal yang dapat membantu dalam proses pertumbuhan tanaman itu sendiri seperti cahaya matahari untuk proses fotosintesis, air sebagai pelarut zat-zat hara dalam tanah yang dapat diserap dari akar tanaman untuk pertumbuhan dan perkembangan tanaman itu sendiri.

\subsection{Jumlah Anakan}

Jumlah anakan merupakan salah satu bagian yang menunjukkan pertumbuhan dan perkembangan tanaman pada fase vegetative. Jumlah anakan dapat digunakan untuk menduga tinggi rendahnya tanaman yang dihasilkan. Hasil pengukuran terhadap jumlah anakan pada tanaman krokot yang mendapat aplikasi pupuk bokashi padat berbahan dasar berbeda dapat dilihat pada Gambar 3.

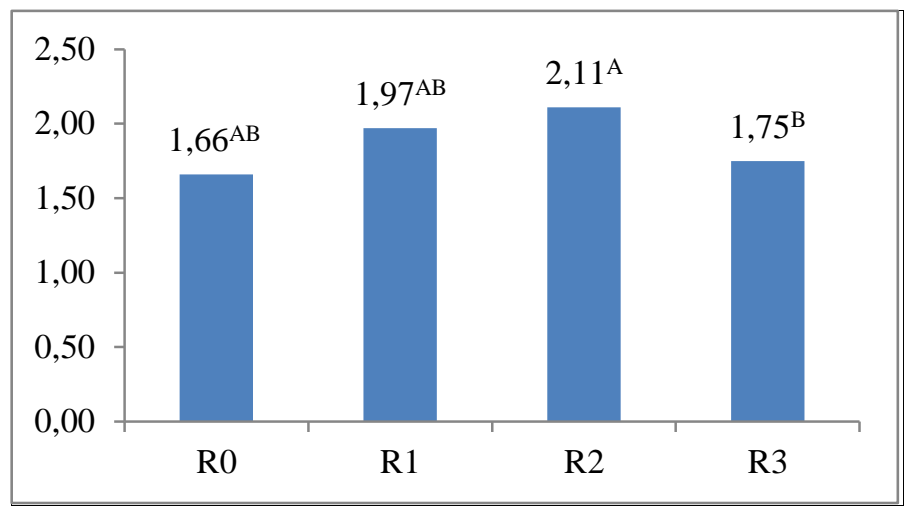

Gambar 3. Data Jumlah Anakan (Tunas). Superskrip yang berbeda pada gambar diatas menunjukkan berbeda nyata $(\mathrm{P}<0,05)$

Data pada Gambar 3 menunjukkan bahwa jumlah anakan terbanyak terdapat pada tanaman krokot yang mendapat perlakuan R2 yakni 2,11 dan dibawahya secara berurutan diikuti oleh perlakuan R1 dengan jumlah anakan 1,97, menyusul perlakuan R3 dengan jumlah anakan 1,75 dan yang paling sedikit ada pada perlakuan R0 dengan jumlah anakan 1,66. Hasil analisis sidik ragam menunjukkan bahwa pemberian bokashi padat berbahan dasar berbeda menghasilkan jumlah anakan yang berpengaruh nyata $(\mathrm{P}<0,05)$. Uji Duncan menunjukkan bahwa hanya pasangan perlakuan $\mathrm{R} 1$ dan $\mathrm{R} 0$ yang menunjukkan tidak berbeda nyata. Perbedaan jumlah anakan ini lebih disebabkan karena perbedaan perlakuan yang diberikan.

Bokashi mengandung mikroorganisme tanah efektif sebagai dekomposer yang dapat mempercepat proses dekomposisi bahan organik dalam tanah, sehingga dapat meningkatkan ketersediaan unsur hara N, P dan K bagi tanaman (Wang et al., 2012; Kaya, 2013). Kandungan organik 5,674, N 0,336, P 21,983 dan K 16,030 (Balitra, 2013). Unsur Nitrogen (N) berfungsi untuk merangsang pertumbuhan vegetatif tanaman secara keseluruhan, khususnya pertumbuhan akar, batang dan daun. Unsur Phosfor (P) berfungsi untuk merangsang pertumbuhan akar, khususnya akar benih dan tanaman muda. Unsur Kalium (K) berfungsi membantu pembentukan protein dan karbohidrat. Pupuk bokashi yang difermentasi dengan EM4, dapat melarutkan fosfat yang tidak tersedia menjadi tersedia bagi tanaman (Wididana, 1997; Ruhukai, 2011).

Tufaila et al. (2014) menyatakan bahwa pupuk bokashi berbahan dasar kotoran sapi mampu mengaktifkan aktivitas sel-sel jaringan meristematik tanaman sehingga akan menghasilkan anakan produktif yang optimal Selanjutnya menurut Sumardi et al. (2007); Soplanit dan Soplanit, (2012) juga menyatakan bahwa pupuk bokashi mengandung mikroorganisme bermanfaat yang merupakan bagian integral dari tanah, mampu menyediakan hara tanaman melalui proses daur ulang serta membentuk struktur tanah yang sesuai untuk pertumbuhan tanaman.

\subsection{Berat Segar Tanaman}

Berat segar tanaman merupakan berat keseluruhan tanaman setelah panen dan sebelum tanaman mengalami layu akibat kehilangan air. Berat segar tanaman merupakan parameter untuk mengetahui biomasa dari pertumbuhan tanaman. Biomasa tanaman merupakan suatu ukuran hasil dari pertumbuhan tanaman yang dihasilkan dari reaksi-reaksi biokimia yang diawali dari penyusunan sel-sel yang akan membentuk jaringan kemudian akan membangun organ hingga pada akhirnya membentuk tubuh tanaman. Hasil pengukuran terhadap berat segar tanaman krokot yang mendapat aplikasi pupuk bokashi padat berbahan dasar berbeda seperti tersaji pada Gambar 4.

Berat segar tanaman merupakan salah satu parameter yang dapat mewakili pertumbuhan tanaman. Semakin besar berat segar tanaman berarti semakin banyak biomasa yang dihasilkan. Pada Gambar 4 terlihat bahwa berat segar tertinggi terdapat pada tanaman krokot yang mendapat perlakuan R2 yakni 3,17 gram dan selanjutnya secara berurutan diikuti oleh perlakuan R1 dengan berat segar 2,93 gram, menyusul perlakuan R3 dengan berat segar 2,80 gram dan yang paling sedikit ada pada perlakuan R0 dengan berat segar 2,09 gram. Hasil analisis sidik ragam menunjukkan bahwa pemberian bokashi padat 
berbahan dasar berbeda menghasilkan jumlah berat segar tanaman yang berbeda tidaknyata. Walau demikian, perlakuan R2 yakni penggunaan pupuk bokashi padat berbahan dasar feses sapi memiliki rataan nilai berat segar tanaman terbaik. Hal ini diduga karena peran dari bokashi berbahan dasar feses sapi kaya akan unsur hara sehingga berkontibusi terhadap pembentukan asimilat juga pada berat segar tanaman. Menurut Noor dan Ningsih (2001), bokashi kotoran sapi merupakan pupuk lengkap, yang mengandung unsur hara makro dan mikro. kandungan unsur hara bokashi kotoran sapi adalah Nitrogen (N) sebesar 092\%, Posfor (P) 0,23\%, Kalium ( K ) 1,03\%, serta mengandung $\mathrm{Ca}, \mathrm{Mg}$, dan sejumlah unsur mikro lainnya seperti $\mathrm{Fe}, \mathrm{Cu}, \mathrm{Mn}, \mathrm{Zn}, \mathrm{Bo}$, dan $\mathrm{Mo}$, yang berfungsi sebagai bahan makanan bagi pertumbuhan dan perkembangan tanaman. Unsur Nitrogen $(\mathrm{N})$ berfungsi dalam pembentukan protein, lemak dan berbagai persenyawaan organik lainnya. Unsur Phosfor $(\mathrm{P})$ berfungsi sebagai pembentukan sejumlah protein tertentu. Unsur Kalium $(\mathrm{K})$ berfungsi untuk memperkuat tanaman sehingga daun, bunga dan buah tidak mudah gugur. Dwidjoseputro, (1994) menyatakan bahwa berat segar tanaman dipengaruh oleh kandungan unsur hara dalam sel-sel jaringan tanaman. Pertumbuhan akar dan daun yang cepat menyebabkan penyerapan unsur hara, air, dan cahaya untuk proses fotosintesislebih optimal, asimilat yang dihasilkan digunakan untuk perkembangan tanaman yang bertambah cepat, sehingga berat segar tanaman akan bertambah. Menurut Foth, (1994), kelembaban tanah penting dalam mempengaruhi laju pergerakan dan fungsi ion ke dalam sel-sel akar, hal ini terkait dengan tingkat kelarutan hara didalam tanah. Ketersediaan air yang meningkat dapat meningkatkan kelarutan $\mathrm{N}$ di dalam tanah, sehingga tanaman mendapatkan pasokan $\mathrm{N}$ yang cukup, akibatnya pertumbuhan vegetatif akan semakin lebat dan berat basah tanaman semakin meningkat. Ratna, (2002) menyatakan bahwa dengan luas daun yang tinggi dapat membentuk dan menyimpan zat hara lebih banyak, sehingga terjadi peningkatan berat basah tanaman. Keberadaan unsur hara yang terkandung dalam pupuk bokashi berbahan Menurut Sitompul dan Guritno, (1995), biomasa tanaman meliputi semua bahan tanaman yang secara kasar, berasal dari hasil fotosintesis, serapan unsur hara dan air yang diolah melalui proses biosintesis.

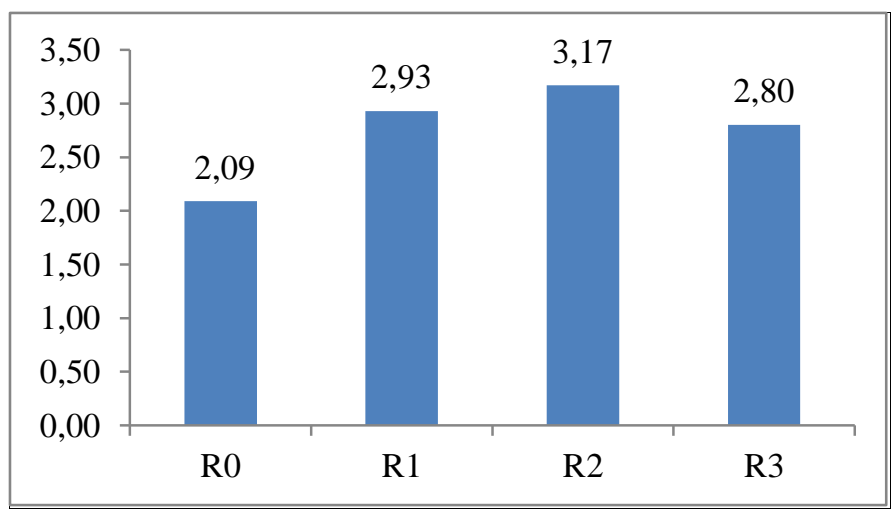

Gambar 4. Data Berat Segar Tanaman (gram)

\subsection{Berat Kering Tanaman}

Berat kering tanaman merupakan parameter pengamatan yang digunakan untuk mengetahui kandungan biomasa dan air yang terkandung pada tanaman berat kering tanaman dilakukan pengamatan dengan cara menimbang berat segar terlebih dahulu setelah diketahui berat segar tanaman kemudian dilakukan pengeringan hingga kadar air yang terkandung hilang kemudian dilakukan penimbangan.Hasil pengukuran terhadap berat kering tanaman krokot yang mendapat aplikasi pupuk bokashi padat berbahan dasar berbeda seperti tersaji pada Gambar 5.

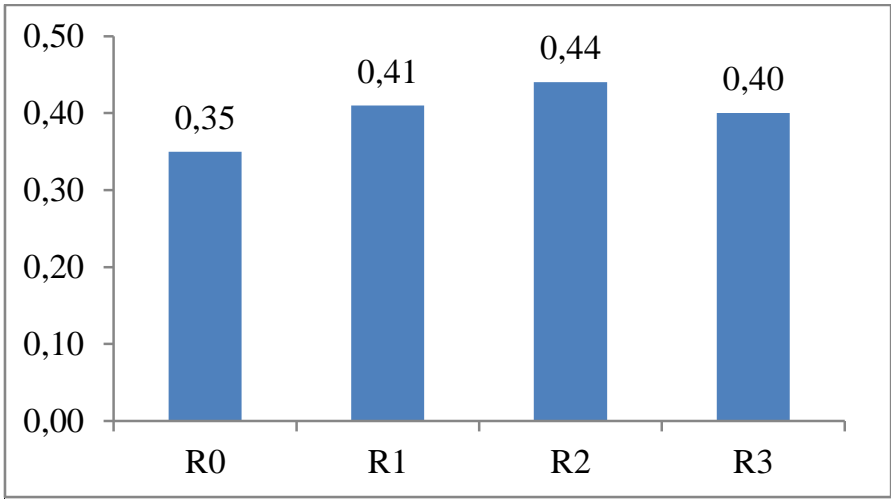

Gambar 5. Data Berat Kering Tanaman (gram)

Berat kering tanaman merupakan salah satu kriteria dalam mengetahui laju pertumbuhan tanaman dengan bertambahnya berat kering daun pada tanaman. Hasil pengukuran berat kering yang ditampilkan pada Gambar 5. Terlihat bahwa berat kering terbaik (berat)t erdapat pada tanaman krokot yang mendapat perlakuan R2 yakni 0,44 gram dan selanjutnya secara berurutan diikuti oleh perlakuan R1 dengan berat kering 0,41 gram, menyusul perlakuan R3 dengan berat kering 0,40 gram dan yang paling sedikit ada pada perlakuan R0 yang hanya seberat 0,35 gram. Hasil analisis sidik ragam (Anova) menunjukkan bahwa pemberian bokashi padat berbahan dasar berbeda berpengaruh tidak nyata terhadapberat kering tanaman krokot. Secara umum perlakuan R2 yakni penggunaan pupuk bokashi padat berbahan dasar feses sapi memiliki rataan nilai berat kering tanaman terbaik. Hal ini diduga dipengaruhi oleh ketersediaan hara, cahaya matahari dan ketersediaan air. Ratna (2002) mengemukakan bahwa apabila unsur hara tersedia dalam kondisi seimbang maka dapat meningkatkan pertumbuhan vegetatif dan bobot kering tanaman Alternatif penerapan teknologi pertanian organik yang berkelanjutan serta berwawasan lingkungan salah satunya dengan penggunaan pupuk bokashi kotoran sapi. Kandungan unsur hara yang tinggi pada kotoran sapi merupakan prospek yang bagus untuk dijadikan pupuk organik (Tufaila et al., 2014). Kandungan unsur hara pada kotoran sapi yaitu N 0,7-1.30\%, P 0,52\%, K $0,95 \%$. Akan tetapi, apabila ketersediaan unsur hara dalam kondisi kurang atau lebih maka akan dihasilkan bobot kering yang rendah. Unsur Nitrogen $(\mathrm{N})$ berfungsi sebagai pembentukan zat hijau daun (klorofil) yang sangat penting untuk melakukan proses fotosintesis. Unsur Phosfor (P) berfungsi untuk membantu proses asimilasi dan pernapasan tanaman. Unsur Kalium (K) berfungsi sebagai salah satu sumber daya tahan tanaman terhadap kekeringan dan penyakit. Selain itu, berat kering tanaman juga dipengaruhi oleh keseimbangan antara pengambilan $\mathrm{O}_{2}$ (fotosintesis) dan pengeluaran $\mathrm{CO}_{2}$ (respirasi). Apabila respirasi lebih besar dibanding fotosintesis, maka berat kering tanaman akan berkurang.

\section{Kesimpulan}

Dari hasil penelitian dan pembahasan, maka dapat disimpulkan bahwa pemberian bokashi padat berbahan dasar ekskreta ayam menghasilkan panjang penyebaran tanaman terbaik yakni $8.53 \mathrm{~cm}$ sedangkan bokashi padat berbahan dasar feses sapi yang terbaik dalam meningkatkan diameter batang $(0,39 \mathrm{~mm})$; jumlah anakan (2,11); berat segar tanaman (3.17 gram) dan berat kering tanaman $(0,44$ gram $)$.

\section{Daftar Pustaka}

Balitra. 2013. Hasil Analisis Tanah Desa Teluk Sarikat Kecamatan Banjang Kabupaten Hulu Sungai Utara. Balai Penelitian Pertanian Lahan Rawa. Banjarbaru.

Dalimartha, S. 2009. Atlas Tumbuhan Obat Indonesia Jilid 6. Pustaka Bunda: Jakarta.

Davis dan Johnson, J. 1987.Eucalyptus Pellita Wild.Forest Scienttist and Consultans. Australia.

Dwidjoseputro, 1994. Pengantar Fisiologi Tumbuhan. Jakarta: PT Gramedia Pustaka Utama.

Foth, H.D. 1994. Dasar- Dasar Ilmu Tanah (Terjemahan Purbayanti, Lukiwati dan Trimutsih "Fundamental Of Soil Science"). Gadjah Mada University Press. Yogyakarta. 782 hal.

Higa, T. dan F.D. James, 1997.Effective Microorganism (EM4). Dimensi Baru. Kyusei

Indriani, Y.H. 2001. Membuat Kompos Secara kilat. Penebar Swadaya Jakarta.

Kaya E. 2013. Pengaruh Kompos Jerami Dan Pupuk NPK Terhadap N-Tersedia Tanah, Serapan-N, Pertumbuhan, Dan Hasil Padi Sawah (Oryza sativa L.). Agrologia. 2(1):43- 50.

Kesumaningwati, R dan Arpendi. 2020. Pengaruh Pemberian bokashi Dengan Menggunakan Bioaktivator Larutan Mikroorganisme (Mol) Keong Mas Terhadap Sifat Kimia Vermikompos. Jurnal Agroekoteknologi Tropika Lembab, 2 (2) : 94-98.

Lingga, P dan Marsono. 2003. Petunjuk Penggunaan Pupuk. Penerbit Swadaya. Jakarta.

Lingga, P. 1996. Petunjuk Penggunaan Pupuk. Penebar Swadaya, Jakarta.

Nasir. 2008. Pengaruh Penggunaan Pupuk Bokashi pada Pertumbuhan dan Produksi Palawija dan Sayuran. www.disperternakpandeglang.go.id/ artikel

Noor, A dan R.D. Ningsih. 2001. Upaya meningkatkan kesuburan dan produktivitas tanah di lahan kering. Dalam. Prosiding Lokakarya Strategi Pembangunan Pertanian Wilayah Kalimantan. Instalasi Penelitian dan Pengkajian Teknologi Pertanian. Banjarbaru

Nguyen, T. H. dan H. Shindo.2011. Effects of Different Levels of Compost Application on Amounts and Distribution of Organic Nitrogen forms in Soil Particle Size Fractions Subjected Mainly to Double Cropping. Journal Agricultural Sciences 2(3): 213-219.

Ratna, D.I. 2002. Pengaruh kombinasi konsentrasi pupuk hayati dengan pupuk organik cair terhadap kualitas dan kuantitas hasil tanaman teh (Camelia sintesis (L). O.Kuntze) Klon Gambung 4. Ilmu Pertanian, 10 (2) : 17-25.

Ruhukai NL. 2011. Pengaruh penggunaan EM4 yang dikulturkan pada bokashi dan pupuk anorganik terhadap produksi tanaman kacang tanah (Arachis hypogaea L.) di Kampung Wanggar Kabupaten Nabire. Jurnal Agroforestri, 6 (2):114-120.

Salisbury, F.B. and Cleon W. Ross. 1995. Fisiologi Tumbuhan Jilid 2. Penerbit ITB, Bandung. 173 hal. 
Sitompul, S. M dan B. Guritno. 1995. Analisis Pertumbuhan Tanaman. Yogyakarta.Gadjah Mada University Press.421 hal.

Soplanit M.Ch, Soplanit R. 2012. Pengaruh bokashi ela sagu pada berbagai tingkat kematangan dan pupuk Sp-36 terhadap serapan $\mathrm{P}$ dan pertumbuhan jagung (Zea mays L.) pada Tanah Ultisol. Agrologia, 1(1):60-68.

Steel, R. G. D., dan J. H. Torrie. 1995. Prinsip dan Prosedur Statistika. Edisi ke-4.Penerbit Gramedia Pustaka Utama, Jakarta. (Diterjemahkan oleh B. Sumantri).

Sumardi M, Kasim, Auzar S, Akhir N. 2007. Respon Padi pada Teknik Budidaya secara Aerobik dan Pemberian Bahan Organik. Jurnal Agrosia, 10(1):65-71.

Syam, A. 2003.Efektivitas Pupuk Organik dan Anorganik Terhadap Produktivitas Padi di Lahan Sawah. Jurnal Agrivigor, 3(3):232-244.

Sutanto, R. 2002. Pertanian Organik: Menuju Pertanian Alternatif dan Berkelanjutan. Kanisius: Yogyakarta.

Taiganides, E. P. 1977. Principles and Techniques of animal waste management and utilization. In: organic Recycling in Asia. FAO Soil Bull, Rome.

Tola F, Hamzah, Dahlan, Kaharuddin.2007, Pengaruh Penggunaan Dosis Pupuk Bokashi Kotoran Sapi Terhadap Pertmbuhan dan Produksi Tanaman Jagung. Jurnal Agrisistem, 3(1):1-8.

Tufaila, M., Yusrina dan S. Alam. 2014. Pengaruh Pupuk Bokashi Kotoran Sapi Terhadappertumbuhan dan Produksi Padi Sawah pada ultisol Puosujaya Kecamatan Konda, Konawe Selatan. Jurnal Agroteknos, 4 (1) $: 18-25$.

Wang S, Liang X, Luo Q, Fan F, Chen Y. and Z. Li. 2012. Fertilization Increases Paddy Soil Organic Carbon Density. Journal of Zhejiang University. 13(4):274-82.

Wididana, G.N. 1997. Bercocok Tanam Padi dengan Teknologi EM4. Departemen Kehutanan. Jakarta.

Winata, N. A. S. H., Karno dan Sutarno. 2012. Pertumbuhan dan Produksi Hijauan Gamal (Gliricidia Sepium) dengan Berbagai Dosis Pupuk Organik Cair. Animal Agriculture Journa1, Vol. 1. No. 1, 2012, p 797 807. 